\title{
Adoption Monitoring Survey Analysis of Conservation Agriculture (CA), Southern Region, Ethiopia
}

\author{
Getahun Degu
}

Senior researcher, Agricultural Economist, SARI/Hawassa Agricultural Research Centre.

Article No.: 052316097

DOI: 10.15580/GJAS.2016.6.052316097

Submitted: $23 / 05 / 2016$

Accepted: 31/05/2016

Published: $24 / 06 / 2016$

${ }^{\star}$ Corresponding Author

Getahun Degu

E-mail: getahundegu@ymail

.com

\section{Keywords:}

Survey, Adoption monitoring,

Conservation agriculture,

Profitability, on-farm trials, sampling, data and descriptive statistics
Conservation agriculture includes on-farm exploratory trials, regarding maize and haricot bean varieties by planting sole and intercrop for both crops. Maize is considered as the main staple crop of the study area and common bean cash crop and protein source of the farmers in many low lands and mid altitude zones of Ethiopia. The country's export earnings from haricot bean exceed that of other pulses such as lentils, horse bean and chickpea. Low production and productivity, which are mainly associated with poor adoption of improved technologies and poor marketing system, were among the major problems. Adoption of improved technologies is one of the most promising ways to reduce food insecurity in Ethiopia. However, the adoption and dissemination of these technologies is constrained by various factors. To this end, the aim of this study was to empirically examine the adoption rate and intensity of adoption of improved conservation technologies vs conventional agriculture in the study area. The snow ball sampling procedures was followed to select sampled households for the study. Six rural kebeles per district were considered as beneficiaries of the CA, and for the three districts, 353 household heads were selected randomly using probability proportional to size sampling. Structured interview schedule was developed, pre-tested and used for collecting the essential quantitative data for the study from the sampled households. Secondary data were collected from relevant sources such as the district office of agriculture and rural development published and unpublished.

The result of the study indicated that majority of farmers in the study area preferred conservation agriculture vs conventional ones regarding their profitability. Moreover, farmers' practice was found largely to deviate from research and extension recommendations. Hence, the adoption monitoring survey result recommended to promote most adopted ones and to modify those activities such as inputs considered as constraints to the reach of farmers by establishing an agribusiness modelling based on the existing farmers' organizations for sustainability of conservation agriculture in the study area. 


\section{INTRODUCTION}

More than $85 \%$ of the Ethiopian population, which resides in the rural area, is engaged in agricultural production as a major means of livelihood (World Bank, 2006). The agricultural production system is mainly rain - fed and traditional, which is characterized by low input of improved seeds, fertilizer, pesticides and other technologies (Legesse, 2004). Moreover, the ever increasing population pressure led to a decline in land holding per household that eventually resulted in low level of production to meet even the consumption requirement of the households (Bezabih and Hadera, 2007).

Increasing agricultural production at the household level is vital to achieve food security (Degnet and Belay, 2001). On the other hand, any marketable surplus could be sold to the non-farming and even to the farming communities (Hailu, 2008). Therefore, increasing the production and productivity in a sustainable manner could address the problem of food shortage (Habtemariam, 2004). As one of the approaches to ensure households food security, the Ethiopian rural development policy and strategy document has given weight to follow diversification and specializations in production systems along with improved access and the use of agricultural technologies (Hailu, 2008).In general, raising agricultural output and productivity on a sustainable basis necessitates large scale adoption and diffusion of new technologies (Mohamed et al., 2009).

\subsection{Significance of the Study}

Adoption studies can provide research and extension staff, rural development institutions, and policy makers with valuable information that improves the efficiency of communication among them in promoting available technologies. Apart from this, acquired information from such studies could enhance the efficiency of agricultural research, technology transfer, input provision, and agricultural policy formulation. All development partners including extension educators, technical assistants, NGOs and other development agents involved in agricultural development must be aware and understand the factors affecting the level of adoption of recommended varieties and agronomic practices for maize-common bean intercropping in order to target and prorate appropriate technologies to farmers.

Sustainable Intensification of Maize-Legume system for Food Security in Eastern and Southern Ethiopia (SIMLESA) program was launched in Ethiopia in March 2010 with the objective of improving the livelihood and eco-system of maize-bean growing smallholder farmers. To this effect the first of the five objectives of the project deals with the characterization of maize-legume production and input and output value chain systems and impact pathways, and identifies broad systemic constraints and options for field testing. An early adoption monitoring survey was designed to capture the adoption process regarding
SIMLISA technologies in the intervention areas. This study provides primary information regarding the status of adoption of these technologies and its implications.

SIMLESA promotes CA-based cropping system:

- Minimum soil disturbance (ideally, zero tillage)

- Soil surface cover (retention of crop residues or live mulches)

- Crop rotation/intercropping involving legume

- Weed control

\subsection{Objective}

- To estimate the economic benefits from the adoption of CA technologies

\section{LITERATURE REVIEW}

\subsection{Definition of Adoption}

Feeder et al. (1985) defined adoption as the degree of use of a new technology in a long-run equilibrium when a farmer has all of the information about the new technology and its potential. Therefore, adoption at the farm level describes the realization of a farmer's decision to implement a new technology. On the other hand, aggregate adoption is the process by which a new technology spreads or diffused through a region. Thus, a distinction exists between adoption at the individual farm level and within a targeted region. If an innovation is modified periodically, however, the equilibrium level of adoption will not be achieved. This situation requires the use of econometric procedures that can capture both the rate and the process of adoption. As the new technology is introduced, some farmers will experiment with it before adopting. The "rate of adoption" is defined as the proportion of farmers who have adopted a new technology at a specific point in time (e.g., the percentage of farmers using fertilizer). Furthermore, the "intensity of adoption" is defined as the level of adoption of a given technology, for example, by the number of hectares planted with improved seed or the amount of fertilizer applied per hectare.

\subsection{Theoretical Background}

The history of adoption and diffusion research can be dated back to the early 1940s beginning with the study of Hybrid maize diffusion in lowa, USA, by the rural sociologists Ryan and Gross (1943). Although the period indicated was taken as an important period with respect to a modern type of adoption and diffusion, there are evidences showing that studies were undertaken on the subject prior to that period. A review of the literature on the adoption of high-yielding seed varieties (Ruttan and Binswanger 1978) suggested that neither farm sizes nor farm tenure has been a 
serious constraint on adoption. Although different rates of adoption by farm size and tenure have been observed, the available data implied that within a few years of introduction, the lags in adoption due to size or tenure have usually disappeared. Of course, the non-adopters would have foregone the potential gains of early adoption and may already have suffered as a consequence. However, these conclusions have not been altered by more recent researches.

Moreover, the results from past studies can be briefly summarized as insight of the adoption of agricultural technologies and its determinants. Research on the diffusion of innovations suggested that the distribution (frequency of adopters over time) tends to follow a bell-shaped curve resembling the normal distribution (Rundiquist, 1984). In its cumulated form, the normal distribution forms the logistic curve which looks like the S-shaped curve often found in adoption studies. Griliches (1957) Mansfield (1961), Mahajan and Robert (1985) and Feeder et al (1985) have discussed the S-shape of the cumulative adoption frequencies plotted over time.

Feder et al. (1985) attributes the diffusion path of aggregate adoption of new technologies to the dynamics of the spread of information. In explaining and interpreting the S-shaped diffusion curve, Mansfield (1961) hypothesized that the rate of adoption is a function of the extent of economic merit of the technology, the amount of investment required to adopt the technology and the degree of uncertainty associated with the technology. Hagerstand (1967) meanwhile, offered an information transfer explanation. In contrast, Sahal (1981) employed a learning perspective when explaining diffusion patterns.

\section{METHODOLOGY}

\subsection{The study area and sampling}

The two study districts were in Sidama zone and the third district was Hallaba special district and these districts were characterized as moisture stress areas and to resolve the problem conservation agriculture was one of the interventions by SIMLESA project since 2012.

The sample size was 353 households for the three districts. Out of these households, 3.3\% were host farmers, $15.8 \%$ second generation, $19.4 \%$ third generation and $61.5 \%$ scale out host farm households. The snowball sampling methods were used to sample the farm households from three districts. The enumerators interviewed the selected household farmers in the SIMLESA program sites. In each district, six peasant associations participated in the program. The analytical technique used for this study is descriptive statistics such as mean, percentage and standard deviation. Descriptive statistics helps to assess and analyze farmers' responses and their implications for adoption of improved maize/common bean varieties.

\section{DEMOGRAPHIC AND SOCIOECONOMIC CHARACTERISTICS}

\subsection{Demographic characteristics}

The mean age of the households ranged from 38 to 42 years old for the three districts. The proportion of female households were 9 (6.3\%), $24(17.9 \%)$ and $2 \%$ (2.4) in the study area respectively. The education status of sampled farmers was categorized as literate and illiterate. Hence, the type of sampled farmers that participated in the early adoption monitoring formal survey were host farmers, second generation, third generation adopters and scale out host (Table 1).

Table 1: Demographic characteristics

\begin{tabular}{|c|c|c|c|c|c|c|}
\hline \multirow[b]{2}{*}{ Characteristics } & \multicolumn{2}{|c|}{ Lockabaya } & \multicolumn{2}{|c|}{ Borecha } & \multicolumn{2}{|c|}{ Hallaba } \\
\hline & Mean & S.D. & Mean & S.D. & Mean & S.D. \\
\hline \multirow{2}{*}{ Age of hhs (yr.) } & 39.40 & 9.57 & 42.28 & 7.44 & 38.41 & 9.33 \\
\hline & $\begin{array}{l}\text { No. of } \\
\text { farmers }\end{array}$ & $\begin{array}{l}\% \text { of } \\
\text { farmers }\end{array}$ & $\begin{array}{l}\text { No. of } \\
\text { farmers }\end{array}$ & $\begin{array}{l}\% \text { of } \\
\text { farmers }\end{array}$ & $\begin{array}{l}\text { No. of } \\
\text { farmers }\end{array}$ & $\begin{array}{l}\% \text { of } \\
\text { farmers }\end{array}$ \\
\hline \multicolumn{7}{|l|}{ Gender of respondent } \\
\hline$-\quad$ Female & 9 & 6.3 & 24 & 17.9 & 2 & 2.4 \\
\hline - Male & 133 & 93.7 & 110 & 82.1 & 83 & 97.6 \\
\hline \multicolumn{7}{|l|}{$\begin{array}{l}\text { Education status of the } \\
\text { household head }\end{array}$} \\
\hline $\begin{array}{c}-\quad \text { Literate } \\
\end{array}$ & 11 & 8.1 & 77 & 57.5 & 11 & 13.3 \\
\hline - Illiterate & 125 & 91.9 & 57 & 42.5 & 72 & 86.7 \\
\hline \multicolumn{7}{|l|}{$\begin{array}{l}\text { Type of farmers in SIMLISA } \\
\text { technology adoption }\end{array}$} \\
\hline$-\quad$ Host farmer & 7 & 4.9 & 5 & 3.7 & - & - \\
\hline $\begin{array}{ll}- & \begin{array}{l}\text { Second generation } \\
\text { adopter }\end{array}\end{array}$ & 18 & 12.7 & 39 & 29.1 & - & - \\
\hline $\begin{array}{ll}\text { - } & \text { Third generation } \\
\text { adopter }\end{array}$ & 35 & 24.6 & 35 & 26.1 & - & - \\
\hline - Scale out host & 82 & 57.7 & 55 & 41 & 85 & 100 \\
\hline
\end{tabular}




\subsection{Socioeconomic Characteristics}

Table 2 shows the land allocation to different enterprises by district. The average total farm size holding ranged from 3 to 4 timad for the three woredas. Similarly, average land allocated under sole maize (hectare) for Hallaba (2.27) was significantly larger compared to Borecha farmers (0.61) and
Lockabaya (0.43). While total land under maize legume (hectare) during 2014 cropping season was significantly larger for Lockabaya farmers $(0.58)$ than Borecha farmers (0.33). Total land under maize rotation (hectare) during the cropping season was significantly larger for Hallaba (1.19) than both lockabaya and Boarecha farmers.

Table 2: land allocation in Lockabaya, Borecha and Hallaba study area

\begin{tabular}{|l|l|l|l|l|l|l|}
\hline \multirow{2}{*}{ Characteristics } & \multicolumn{2}{|l|}{ Lockabaya } & Borecha & \multicolumn{2}{l|}{ Hallaba } \\
\cline { 2 - 7 } & Mean & $\begin{array}{l}\text { Standard } \\
\text { deviation } \\
\text { (S.D.) }\end{array}$ & Mean & $\begin{array}{l}\text { Standard } \\
\text { deviation } \\
\text { (S.D.) }\end{array}$ & Mean & $\begin{array}{l}\text { Standard } \\
\text { deviation } \\
\text { (S.D.) }\end{array}$ \\
\hline Total farm size holding (timad) & 4.44 & 2.82 & 3.07 & 2.16 & 5.99 & 3.72 \\
\hline $\begin{array}{l}\text { Average land allocated under } \\
\text { sole maize (hectare) }\end{array}$ & 0.43 & 0.44 & 0.58 & 0.61 & 2.27 & 1.64 \\
\hline $\begin{array}{l}\text { Average land allocated under } \\
\text { legume (hectare) }\end{array}$ & 0.16 & 0.17 & 0.33 & 0.35 & 1.45 & 1.15 \\
\hline $\begin{array}{l}\text { Total land under maize legume } \\
\text { (hectare) during 2014 cropping } \\
\text { season }\end{array}$ & 0.74 & 2.10 & 0.33 & 0.36 & 0.73 & 0.51 \\
\hline $\begin{array}{l}\text { Total land under maize rotation } \\
\text { (hectare) during 2014 cropping } \\
\text { season }\end{array}$ & 0.13 & 0.18 & 0.13 & 0.19 & 1.19 & 1.71 \\
\hline
\end{tabular}

Source: Sample survey, 2014

One timad: $0.25 \mathrm{ha}$

\subsubsection{Livestock production}

Livestock are the main sources of income and also used as draught power. Farmers in Hallaba significantly owned more number of cows and oxen's (5.18) than both Lockabaya (4.10) and Borecha farmers (3.24). Farmers in Hallaba owned more number of sheep and goat (4.34). Borecha owned more number of chickens (8.75) than both Hallaba (6.82) and Lockabaya (5.47).

Table 3: The mean number of livestock in the study area

\begin{tabular}{|l|l|l|l|l|l|l|}
\hline \multirow{2}{*}{ Characteristics } & \multicolumn{2}{|c|}{ Lockabaya } & \multicolumn{2}{c|}{ Borecha } & \multicolumn{2}{c|}{ Hallaba } \\
\cline { 2 - 8 } & Mean & $\begin{array}{l}\text { Standard } \\
\text { deviation } \\
\text { (S.D.) }\end{array}$ & Mean & $\begin{array}{l}\text { Standard } \\
\text { deviation } \\
\text { (S.D.) }\end{array}$ & Mean & $\begin{array}{l}\text { Standard } \\
\text { deviation } \\
\text { (S.D.) }\end{array}$ \\
\hline Number of cows and ox & 4.10 & 2.64 & 3.24 & 1.92 & 5.18 & 3.64 \\
\hline Number of bulls and heifers & 1.59 & 1.79 & 1.62 & 1.15 & 1.23 & 1.27 \\
\hline Number of sheep and goat & 2.96 & 3.12 & 4.03 & 3.65 & 4.34 & 3.79 \\
\hline $\begin{array}{l}\text { Number of horses, mules and } \\
\text { donkeys }\end{array}$ & 0.21 & 0.89 & 0.31 & 0.69 & 1.42 & 0.96 \\
\hline Number of chickens & 5.47 & 3.06 & 8.75 & 6.06 & 6.82 & 3.66 \\
\hline
\end{tabular}

\section{ADOPTION OF CA TECHNOLOGIES}

Farmers who were aware of activities conducted by SIMLESA program as shown in Annex 1 indicate, $98.6 \%$ for Lockabaya, Borecha $85.8 \%$ and Hallaba $98.8 \%$. Those farmers hosting SIMLISA demonstration were 9.7, 54.2 and 98.8 percent for the three districts respectively. While those that participated in members innovation platform accounted to $43 \%$ for Lockabaya and $43.6 \%$ for Borecha. During the survey, the innovation platform not established in Hallaba due to budget constraint. Those that participated in visited demonstration, participated in 
attended field days, participated in exchange visits also pinpointed in the Annex table one.

The types of technologies adopted were maize-bean intercropping as of $35.9 \%, 77.4 \%$ and $65.9 \%$ for the three districts accordingly followed by minimum/zero tillage $47.2 \%$ for Lockabaya, $15.8 \%$ for Borecha $24.7 \%$ for Hallaba. The sources of information, SIMLESA demonstration/host farmers $63 \%, 54 \%$ and $53 \%$ for the three districts followed by extension workers as of $24 \%, 38 \%$ and $33 \%$ of the sampled farmers in the respective districts.

Sampled farmers who expanded their plots beyond SIMLESA demonstration estimated as $76 \%$, $44 \%$ and $97 \%$ for the three districts. The share of knowledge on the technology was $76 \%, 82 \%$ and $100 \%$. This is a good indicator for the enhancement of adoption of improved SIMLESA technologies which are further to be scaled up/out based on early adoption monitoring survey results and the profitability study. The percentage change in yield due to the technology, $63 \%, 44 \%$ and $8 \%$ accordingly for the three districts.

\section{Profitability of conservation agriculture}

The profitability study was based on the exploratory trials conducted in the land of farmers selected voluntary in the three districts. The summary of the total cost of the different treatments were depicted in Annex table 2.

Table 5 shows the gross margin of conservation and conventional tillage practice and the profitability analysis; it showed that CA has a net benefit of $48 \%$ compared to the conventional tillage (Intercropping of $\mathrm{MZ}+\mathrm{CB} 1+\mathrm{CB} 2)$. All the other treatments for the conservation have been profitable. The agronomic practices were herbicide application before planting, minimum tillage using ripper for sowing of the maize and common bean seed intercropped, one to two supplementary weeding, after harvest mulching the field with maize stocks (75\%). Common bean also relay cropped as B2).

Table 5: Gross margin of Conservation Vsc Conventional tillage practices, 2014.

\begin{tabular}{|l|l|c|c|c|c|}
\hline Treatment & $\begin{array}{l}\text { Mean yield } \\
\text { qt/ha }\end{array}$ & $\begin{array}{l}\text { Cost } \\
\text { Birr/ha }\end{array}$ & $\begin{array}{l}\text { Benefit } \\
\text { Birr/ha }\end{array}$ & $\begin{array}{l}\text { Profit } \\
\text { Birr/ha }\end{array}$ \\
\hline $\begin{array}{l}\text { Conservation } \\
\text { Agriculture }\end{array}$ & Sole Maize (MZ) & 69.34 & 6306 & 34,670 & $\mathbf{2 7 , 9 8 4}$ \\
\cline { 2 - 6 } & $\begin{array}{l}\text { Sole Common Bean (CB1+ } \\
\text { CB2) }\end{array}$ & $20.37 / 18.41$ & 3528.25 & 31,024 & $\mathbf{2 7 , 4 9 5 . 7 5}$ \\
\cline { 2 - 6 } & $\begin{array}{l}\text { Intercropping (MZ + CB1+ } \\
\text { CB2) }\end{array}$ & $70.09 / 26.71$ & 9106 & 56,413 & $\mathbf{4 7 , 3 0 7}$ \\
\cline { 2 - 6 } & Intercropping (MZ+CP1+CP2) & $69.57 / 23.76$ & 9984.25 & 53,793 & $\mathbf{4 3 , 8 0 8 . 7 5}$ \\
\cline { 2 - 6 } & Rotation (MZ) & 72.78 & 6356 & 36,390 & $\mathbf{3 0 , 0 3 4}$ \\
\hline $\begin{array}{l}\text { Conventional } \\
\text { Agriculture }\end{array}$ & $\begin{array}{l}\text { Intercropping (MZ+ } \\
\text { CB1+CB2) }\end{array}$ & $64.33 / 18.46$ & 14244.25 & 46,933 & $\mathbf{3 2 , 6 8 8 . 7 5}$ \\
\hline
\end{tabular}

Source: Own manipulation

\section{CONCLUSION}

The monitoring adoption survey has provided primary information regarding CA technologies awareness, adoption and its dis-adoption. Based on the results, it is advisable to promote most adopted ones and to modify those activities such as inputs considered as constraints to reach a considerable number of farmers. Hence, this shortcoming should be resolved through the establishment of small farmers groups (youths) to deliver inputs to the respective peasant kebele's through agribusiness model to be capacitated by SIMLESA program to attain the sustainability of conservation agriculture in the study area based on the existing farmers' organizations. Therefore, policy and development interventions should give emphasis to institutionalizing the successful SIMLESA technologies and agronomic practices to accomplish wider adoption, increased productivity and income to small scale farmers. 


\section{APPENDICES}

Annex 1. Awareness, Adoption and dis-adoption of SIMLESA technologies

\begin{tabular}{|c|c|c|c|c|c|c|}
\hline \multirow{2}{*}{$\begin{array}{c}\text { Characteristics } \\
\text { Are you aware of SIMLESA } \\
\text { technologies in your area? }\end{array}$} & \multicolumn{2}{|c|}{ Lockabaya } & \multicolumn{2}{|c|}{ Borecha } & \multicolumn{2}{|c|}{ Hallaba } \\
\hline & $\begin{array}{c}\mathrm{N} \text { of } \\
\text { farmers }\end{array}$ & $\begin{array}{c}\% \text { of } \\
\text { farmers }\end{array}$ & $\begin{array}{c}\mathrm{N} \text { of } \\
\text { farmers }\end{array}$ & $\begin{array}{c}\% \text { of } \\
\text { farmers }\end{array}$ & $\begin{array}{c}\mathrm{N} \text { of } \\
\text { farmers }\end{array}$ & $\begin{array}{c}\% \text { of } \\
\text { farmers }\end{array}$ \\
\hline$-\quad$ Yes & 28 & 98.6 & 72 & 85.5 & 84 & 98.8 \\
\hline- No & 2 & 1.4 & 2 & 1.5 & 1 & 1.2 \\
\hline \multicolumn{7}{|l|}{$\begin{array}{l}\text { If yes hosting SIMLESA } \\
\text { demonstration }\end{array}$} \\
\hline- Yes & 28 & 9.7 & 72 & 54.2 & 84 & 98.8 \\
\hline$-\quad$ No & 114 & 80.3 & 61 & 45.9 & 1 & 1.2 \\
\hline \multicolumn{7}{|l|}{$\begin{array}{l}\text { Participated in member of } \\
\text { innovation platform }\end{array}$} \\
\hline- Yes & 61 & 43 & 58 & 43.6 & - & - \\
\hline$-\mathrm{No}$ & 81 & 57 & 75 & 56.4 & 85 & 100 \\
\hline \multicolumn{7}{|l|}{$\begin{array}{l}\text { Participated in visited } \\
\text { demonstration }\end{array}$} \\
\hline$-\quad$ Yes & 128 & 90.1 & 99 & 74.4 & 82 & 96.5 \\
\hline- No & 14 & 9.9 & 34 & 25.6 & 3 & 3.5 \\
\hline \multicolumn{7}{|l|}{$\begin{array}{l}\text { Participated in attended field } \\
\text { days }\end{array}$} \\
\hline- Yes & 96 & 67.6 & 93 & 69.9 & 81 & 95.3 \\
\hline No & 46 & 32.4 & 40 & 30.1 & 4 & 4.7 \\
\hline \multicolumn{7}{|l|}{ Participated in exchange Visit } \\
\hline- Yes & 45 & 31.7 & 7 & 5.3 & 64 & 75.3 \\
\hline- No & 97 & 68.3 & 126 & 94.7 & 21 & 24.7 \\
\hline \multicolumn{7}{|l|}{$\begin{array}{l}\text { Participated in others, extension } \\
\text { activities }\end{array}$} \\
\hline- Yes & 78 & 61.2 & 51 & 38.3 & 11 & 12.9 \\
\hline No & 97 & 68.3 & 126 & 94.7 & 21 & 24.7 \\
\hline \multirow{2}{*}{ Characteristics } & \multicolumn{2}{|c|}{ Lockabaya } & \multicolumn{2}{|c|}{ Borecha } & \multicolumn{2}{|c|}{ Hallaba } \\
\hline & $\begin{array}{c}\mathrm{N} \text { of } \\
\text { farmers }\end{array}$ & $\begin{array}{c}\% \text { of } \\
\text { farmers }\end{array}$ & $\begin{array}{c}\mathrm{N} \text { of } \\
\text { farmers }\end{array}$ & $\begin{array}{c}\% \text { of } \\
\text { farmers }\end{array}$ & $\begin{array}{c}\mathrm{N} \text { of } \\
\text { farmers }\end{array}$ & $\begin{array}{c}\% \text { of } \\
\text { farmers }\end{array}$ \\
\hline \multicolumn{7}{|l|}{ Technologies adopted } \\
\hline - Maize bean Intercropping & 51 & 35.9 & 103 & 77.4 & 56 & 65.9 \\
\hline - $\quad$ Minimum/zero tillage & 67 & 47.2 & 21 & 15.8 & 21 & 24.7 \\
\hline Shalla & 13 & 9.2 & 2 & 1.5 & - & - \\
\hline - $\quad$ Ripper & 2 & 1.4 & - & - & 6 & 7.1 \\
\hline $\begin{array}{l}\text { Others (BH 540, } \\
\text { HawassaDume, Sole } \\
\text { maize, maize bean } \\
\text { rotation) }\end{array}$ & 7 & 4.9 & 3 & 2.3 & - & - \\
\hline \multicolumn{7}{|l|}{ Source of information } \\
\hline $\begin{array}{ll} & \text { SIMLESA demo/host } \\
\text { farmer }\end{array}$ & 87 & 63 & 77 & 54 & 45 & 53 \\
\hline - $\quad$ Extension workers & 33 & 24 & 54 & 38 & 28 & 33 \\
\hline - Other fellow farmers & 18 & 13 & 12 & 8 & 12 & 14 \\
\hline \multicolumn{7}{|l|}{$\begin{array}{l}\text { If stopped, using it gave main } \\
\text { reason }\end{array}$} \\
\hline - Unavailability of herbicide & 127 & 90 & 106 & 79 & 85 & 85 \\
\hline - $\quad$ Lack of seed & 8 & 5 & 24 & 18 & 9 & 9 \\
\hline - Livestock feed shortage & 6 & 3 & 5 & 3 & 6 & 6 \\
\hline \multicolumn{7}{|l|}{ Name of technology liked most } \\
\hline $\begin{array}{ll} & \text { Minimum/Zero tillage }\end{array}$ & 40 & 29 & 36 & 26 & 22 & 30 \\
\hline $\begin{array}{ll}- & \text { Maize/bean intercropping }\end{array}$ & 9 & 7 & 9 & 6 & 43 & 58 \\
\hline - $\quad$ Maize bean rotation & 1 & 0.5 & 2 & 7 & 3 & 4 \\
\hline - $\quad$ Sole maize cropping & 0 & - & 18 & 13 & 5 & 6 \\
\hline - Shalla & 8 & 6 & 39 & 28 & 1 & 2 \\
\hline$-\quad \mathrm{BH}-540$ & 67 & 48 & 0 & - & 0 & - \\
\hline - Gebi & 1 & 0.5 & 1 & 3 & 0 & - \\
\hline
\end{tabular}




\begin{tabular}{|c|c|c|c|c|c|c|}
\hline \multirow{3}{*}{$\begin{array}{l}\text { Ibado } \\
\text { Characteristics }\end{array}$} & 13 & 9 & 22 & 16 & 0 & - \\
\hline & \multicolumn{2}{|c|}{ Lockabaya } & \multicolumn{2}{|c|}{ Borecha } & \multicolumn{2}{|c|}{ Hallaba } \\
\hline & $\begin{array}{c}\mathrm{N} \text { of } \\
\text { farmers }\end{array}$ & $\begin{array}{c}\% \text { of } \\
\text { farmers }\end{array}$ & $\begin{array}{c}\mathrm{N} \text { of } \\
\text { farmers }\end{array}$ & $\begin{array}{c}\% \text { of } \\
\text { farmers }\end{array}$ & $\begin{array}{c}\mathrm{N} \text { of } \\
\text { farmers }\end{array}$ & $\begin{array}{c}\% \text { of } \\
\text { farmers }\end{array}$ \\
\hline \multicolumn{7}{|l|}{$\begin{array}{l}\text { Expanded plot beyond SIMLISA } \\
\text { demonstration }\end{array}$} \\
\hline- Yes & 25 & 76 & 44 & 44 & 72 & 97 \\
\hline$-\quad$ No & 8 & 24 & 56 & 56 & 1 & 3 \\
\hline \multicolumn{7}{|l|}{ If not expanded? First reason } \\
\hline$-\quad$ Lack of seed & - & - & 41 & 67 & 10 & 100 \\
\hline - $\quad$ Livestock feed shortage & 1 & 100 & 9 & 15 & - & - \\
\hline - $\quad$ Lack of herbicide & - & - & 5 & 8 & - & - \\
\hline$-\quad$ Fuel wood shortage & - & - & 6 & 10 & 0 & - \\
\hline \multicolumn{7}{|l|}{ Share knowledge on technology } \\
\hline- Yes & 25 & 76 & 77 & 82 & 74 & 100 \\
\hline - No & 8 & 24 & 17 & 18 & - & \\
\hline \multirow[t]{2}{*}{ Characteristics } & \multicolumn{2}{|c|}{ Lockabaya } & \multicolumn{2}{|c|}{ Borecha } & \multicolumn{2}{|c|}{ Hallaba } \\
\hline & Mean & S.D & Mean & S.D & Mean & S.D \\
\hline $\begin{array}{l}\text { Area (hectare) under SIMLESA } \\
\text { technology before }\end{array}$ & 0.21 & 0.13 & 0.20 & 0.11 & 0.53 & 0.36 \\
\hline $\begin{array}{l}\text { Area (hectare) under SIMLESA } \\
\text { technology after }\end{array}$ & 0.44 & 0.40 & 0.75 & 0.98 & 0.86 & 0.31 \\
\hline $\begin{array}{l}\text { Percent change in yield due to } \\
\text { technology }\end{array}$ & 9.94 & 62.59 & 163.28 & 43.76 & 34.28 & 7.86 \\
\hline
\end{tabular}

Source: Sample survey, 2014

Annex 2: Summary of the total Cost that vary/hectare, for Hawassa ,Borecha and lockabaya districts, 2014

\begin{tabular}{|c|c|c|c|c|c|c|c|c|c|}
\hline \multirow[t]{3}{*}{$\begin{array}{l}\text { Operational } \\
\text { activities }\end{array}$} & \multicolumn{7}{|c|}{ Conservation agriculture } & \multirow{2}{*}{\multicolumn{2}{|c|}{$\begin{array}{c}\begin{array}{c}\text { Conventional } \\
\text { Agriculture }\end{array} \\
\text { Intercropping } \\
\end{array}$}} \\
\hline & \multirow[t]{2}{*}{ Maize } & \multirow{2}{*}{$\begin{array}{l}\text { CB1\& } \\
\text { CB2 }\end{array}$} & \multicolumn{3}{|c|}{ Intercropping } & \multicolumn{2}{|c|}{ Rotation } & & \\
\hline & & & $\begin{array}{l}\text { Maiz } \\
\text { e }\end{array}$ & $\begin{array}{l}\text { CB1\&C } \\
\text { B2 }\end{array}$ & $\begin{array}{l}\text { CP1\&C } \\
\text { P2 }\end{array}$ & Maize & CB & Maize & $\begin{array}{l}\text { CB1\&C } \\
\text { B2 }\end{array}$ \\
\hline Land preparation & 0 & 0 & 0 & 0 & 0 & 0 & - & 2400 & 2200 \\
\hline $\begin{array}{l}\text { Raw spacing } \\
\text { (rippers) }\end{array}$ & 600 & 600 & 600 & 600 & 600 & 600 & - & 0 & 0 \\
\hline Seeds & 930 & 1200 & 930 & 1200 & 600 & 930 & - & 930 & 1200 \\
\hline Labor for planting & 400 & 400 & 350 & 300 & 300 & 350 & - & 300 & 250 \\
\hline $\begin{array}{l}\text { Chemical fertilizer } \\
\text { (DAP \&Urea) }\end{array}$ & 2426 & 628.25 & 2426 & 0 & 628.25 & 2426 & - & 2426 & 628.25 \\
\hline $\begin{array}{l}\text { Labor for Fertilizer } \\
\text { application }\end{array}$ & 400 & - & 350 & - & - & 350 & - & 300 & 250 \\
\hline Weeding & 800 & 700 & 800 & 700 & 700 & 800 & - & 1760 & 1600 \\
\hline Herbicide & 450 & - & 450 & - & 450 & 450 & - & 0 & 0 \\
\hline $\begin{array}{l}\text { Labor for herbicide } \\
\text { spraying }\end{array}$ & 200 & - & 150 & - & - & 150 & - & - & - \\
\hline Total Cost & 6306 & $\begin{array}{c}4178.2 \\
5 \\
\end{array}$ & 6356 & 2800 & 3678.25 & 6356 & - & 8116 & 6128.25 \\
\hline
\end{tabular}

Note: $\mathrm{CB} 1=$ Common bean planted in Belg; $\mathrm{CB} 2=$ Common bean planted in Meher; $\mathrm{CP} 1=\mathrm{Cow}$ pea planted in

Belg and CP2 = Cow pea planted in Meher 
Annex 3: Average prices of agricultural inputs

\begin{tabular}{|l|c|}
\hline Inputs & Price In Birr \\
\hline Abaraya/qt & 3800.00 \\
\hline Common bean -HawassaDume/qt & 1600.00 \\
\hline Fertilizer Maize - DAP/100kg & 1377.48 \\
- Urea/100kg & 1101.68 \\
\hline Herbicide - 1 It/ha (Round up) & 180.0 \\
\hline Insecticide: 1lt/ha (Karate) & 400.00 \\
\hline \multicolumn{2}{|c|}{ Source: Woreda Agricultural Offices, 2015 }
\end{tabular}

\section{ACKNOWLEDGEMENT}

This study was financially supported by SIMLESA through EIAR/SARI. The author wish to thank Daniel Markos, an agronomist who collaborate with socioeconomics researchers and also other team members.

\section{REFERENCES}

BezabihEmana. andHadera G/medhin. 2007. "Constraints and Opportunities of Horticulture Production and Marketing in Eastern Ethiopia". DCG Report No.46.

DegnetAbebaw and Belay Kasa .2001. 'Factors Influencing Adoption of High Yielding Maize Varieties in South West Ethiopia: An Application of Logit Analysis', Quarterly Journal of International Agriculture, Vol.40, No.2, Pp. 149-67.

DegnetAbebaw, B. Kassa, and A.Waktola, 2001.Adoption of High Yielding Varieties of Maize in JimmaZone.Evidence from Farm Level Data.Journal of Agricultural Economics.Vol. 5 (1\&2).

Feder, G., R. E.Just and D. Zilberman. 1985. "Adoption of agricultural innovations in developing countries: A survey." Economic development and cultural change, 33:255-99.

Habtemariam Abate, 2004. The comparative Influence of Intervening variable in the adoption of Maize and DairyFarmersin Shashemene and Debrezieit, Ethiopia. PhD Thesis, University of Pretoria.
Hagerstrand, T. 1967. Innovation diffusion as a spatial process. University of Chicago, Chicago press, Chicago.

Hailubeyene, 2008. Adoption of improved teff and wheat production in crop livestock mixed system in northernand western shewa zones of Ethiopia Ph. D. Thesis University of Pretoria,. Johnston, J. and Dandiro, J., 1997. Econometrics Methods, fourth Edition, New York: McGraw Hill Companies, Inc.

Mahajan, V. and R.A. Peterson .1985. Models for innovation diffusion.sage university paper series on qualitative applications in the social sciences, series no 07-048. Beverely hills london sage pubns.

Mansfield, E. 1961."Technical change and the rate of imitation" Econometrica,29:741-66.

Rundiquistand Franz-Michael. 1984. Hybrid maize diffusion in Kenya. Land University, CWK. Gleerup.

Ruttan, V.W. and H.P. Binswanger. 1978. "Induced innovation and the green revolution." In Binswanger H.P.and V.W. Ruttan (eds).Induced innovation: Technology, institutions, and development. Baltimore: Johns Hopkins University Press.

Sahal, D. 1981. Patterns of technological Innovation. Reading, MA: Adison, Wesley.

World Bank, 2006. Africa Development indicators 2006. Washington DC. Wortmann, C.S. and C. A. Eledu 1997. Distribution of bean types in Eastern Africa.Annual Report of the Bean Improvement Cooperative. $\quad 40: \quad 30-31$. 